\title{
IMPACT OF SYNGAS ON MAXIMAL SPARK IGNITION ENGINE POWER
}

\author{
Karol Tucki, Remigiusz Mruk, Katarzyna Botwinska \\ Warsaw University of Life Sciences, Poland \\ karol_tucki@sggw.pl, remigiusz_mruk@sggw.pl, katarzyna_botwinska@wp.pl
}

\begin{abstract}
The constant increase in demand for energy and its carriers and the growing normative requirements in terms of eco-friendliness and reduction of $\mathrm{CO}_{2}$ emissions make it necessary to look for new sources of energy supply. Decreasing resources of conventional energy sources, including oil, the dynamic development of the road transport sector and the consequent increase in the number of vehicles on the roads have a negative impact on the air and environment. This makes it necessary to systematically increase the share of biofuels to minimise the negative environmental impact. It should be stressed that all new solutions must be sustainable and take into account the care of the environment. The manuscript analyses the possibilities of using alternative sources of automotive engine propulsion, with a particular focus on wood gas, petrol, methane and LPG (Liquefied Petroleum Gas). Using the example of a car equipped with the 1.1 Fire engine, a computer simulation has been developed to reproduce the NEDC (New European Driving Cycle) driving cycle. The simulation model used in the analysis was developed in Scilab environment. The computer simulation scheme consisted of five blocks taking into account the contour characteristics maps of the engine under analysis. As the results of the simulation have shown, when the engine is powered by wood gas, there is a significant drop in power. This is due to the much lowerc alorific value of woodgas and the lower air demand for the conversion of the fuel unit. Methaneturned out to be a carrier with parameters more similar to those of conventional fuel. In this case, there has been a smaller decrease in the power achieved by the engine.
\end{abstract}

Keywords: SI engine, spark ignition, wood gas, syngas, Scilab simulations.

\section{Introduction}

The rapid progress of civilization that began in the 20th century and continues to this day is largely based on obtaining energy from non-renewable resources. Oil, coal and natural gas are still the basis of modern fuels or occur as independent energy carriers [1]. The process of their re-emergence in the natural environment is estimated at billions of years, which is why it is impossible to wait for the renewal or increase of those resources. With the constantly growing demand for energy, the depletion of conventional sources is an undeniable occurrence that may result in a global energy crisis [2]. At present, energy security, i.e. constant access to energy sources at an affordable price, has a key role in the policies of countries and communities, which is why it is extremely important to obtain fuels from renewable sources, which will also be consistent with the principles of sustainable development so as not to cause degradation of the natural environment and not to compete with raw materials intended for consumption [3; 4].

One of the sectors with high energy consumption is transport, including road transport, which contributes to increased consumption of transport fuels due to the continuous increase in the fleet of vehicles [5]. To reduce the use of conventional raw materials and the negative impact on the environment, including atmospheric air, biofuels and bio-additives are used. The development of electromobility is also important [6]. Increasingly, cars equipped with hydrogen propulsion, which is considered the future of the automotive industry, are appearing on the market. The only substance emitted by a car with this type of propulsion is environmentally neutral water, which, if used on a large scale, means there is significant potential for reducing $\mathrm{CO}_{2}$ emissions in transport $[7 ; 8]$. The best known methods for obtaining hydrogen include: natural gas reforming, coal or coke gasification, plasma technology, water electrolysis, photoelectrolysis, biological methods. In the reforming process, $8.34 \mathrm{~kg}$ of carbon dioxide is produced per $1 \mathrm{~kg}$ of hydrogen in the hydrogen production installation alone [9]. The hydrogen oxidation process itself in a hydrogen cell car is a completely zero emission process, i. e. the only emission is pure steam/water. Nevertheless, it should be stressed that on average $1 \mathrm{~kg}$ of hydrogen is sufficient to travel 100 kilometres, i. e. at best $1 \mathrm{~kg}$ of hydrogen obtained from coal generates $8.34 \mathrm{~kg}$ of carbon dioxide (without taking into account energy expenditure during coal mining and transport - there are no such literature data). Comparing the emissions of a combustion car (5-6 litres of fuel, distance $100 \mathrm{~km}, 11.8-14.1 \mathrm{~kg}$ of $\mathrm{CO}_{2}$ emission) a hydrogen car will be cleaner than an average petrol car [10]. 
For diesel, vegetable oils and their esters can be alternative fuels. Practical market applications have methyl esters of fatty acids are used as a mixture with classic diesel fuel, up to $10 \%$ of the volume. In the case of petrol, the alternative is alcohol, mainly bioethanol whose content in common use is also up to $10 \%[11,12]$. The third largest transport fuel consumption is LPG. Its consumption as an energy carrier for vehicles is steadily increasing across the world [13]. The gas is obtained during oil extraction and refining, thereby it is closely related to the extraction of non-renewable resources. LPG does not have its renewable counterpart, which would have been put into widespread use [14]. Wood gas and methane are energy carriers which, on the one hand, are sustainable and, on the other, can be an alternative to conventional LPG. These gases are obtainable from biomass, i.e. renewable raw materials, often waste fractions, which would thus be subject to favourable recycling. Conventional methane is formed below the surface of the earth in the process of anaerobic decomposition of organic fractions. Its significant amounts are found in natural gas and hard coal. This gas is also obtainable in biogas plants in the process of fermentation of plant biomass (including waste) or municipal waste. After purification and conditioning to natural gas parameters, it can be used as transport fuel in NGV's (natural gas vehicles) [15]. Wood gas, also called synthesis gas or syngas, is produced in gas generators as a result of thermal transformation of solid biomass (wood) into a gaseous fuel [16]. Wood gas was already used to power vehicles, mainly during World War II due to petrol limits resulting from war operations. The technology developed by the French engineer J. Imbert was used by large automotive companies such as Ford, Mercedes-Benz and General Motors [17]. Poor power supply efficiency, inconvenient operation, the additional installation with which the vehicle had to be equipped, and the health risk of carbon monoxide that escaped during the conversion of gaseous fuel and the widespread availability of petrol have all contributed to the displacement of wood gas technology as a fuel for motor vehicles [18; 19]. Wood gas can be used in internal combustion engines, however, it causes their power to decrease. This is due to the lower air demand required to burn $1 \mathrm{~m}^{3}$ of gas. This medium also has a lower combustion temperature, which translates into lower pressure, which in turn reduces engine torque. Lower power and torque reduce the efficiency of the internal combustion engine and reduce the vehicle's driving performance. Moreover, depending on the production technology and substrates, the gas extracted from wood biomass contains dust and tar substances, which can damage the drive unit without thorough cleaning [20;21].

Due to numerous inconveniences and the restoration of the availability of conventional fuels, syngas ceased to be used in transport and its use shifted to the heating sector. However, due to the specificity of waste wood biomass and the amount of harvestable wood waste fractions, it is worth considering the possibility of reusing this energy carrier.

Considering the above, it was decided to analyse the possibilities of supplying the petrol internal combustion engine with alternative gas fuels to determine their potential for the possible replacement of nearly depleted conventional carriers. In order for alternative fuels to enter the market circuit, they must have similar parameters to conventional fuels. A fairly important feature is also an affordable, economically justified production technology that will make it possible to supply the carrier in bulk quantities [22].Therefore, the results were compared with 95 petrol and LPG, i.e. typical energy carriers for the spark engine.

\section{Materials and methods}

While analysing the possibility of using energy carriers not introduced for general use, one should bear in mind the potential negative impact on the selected research object, or even its destruction. In order to prevent damage to a real object, this paper uses computer simulation that reflects the operation of the internal combustion engine in a passenger car. These types of simulations have many advantages that simplify the research process of individual phenomena. Thanks to high computational capabilities, simulation models provide significant amounts of data in a short time and with virtually no cost borne, and the results obtained can be the basis for non-invasive real experiments [23, 24].

In order to build the simulation model, the SciLab program was employed, which is a scientific environment for performing various numerical calculations and creating block diagrams that reflect processes and dependencies in real objects. In its functionality, SciLab refers to the widely used MATLAB program, however, it is an open source alternative for the latter. The simulation developed consists of four sections, each being responsible for setting individual engine operating parameters, 
necessary to determine the operational values of individual fuels (in the fifth section). The individual blocks of the simulation model are described below:

- Section I "Driving test generator" - Responsible for generating signals necessary to ensure correct control of the simulation. In this block, signals of the vehicle speed $\left[\mathrm{m} \cdot \mathrm{s}^{-1}\right]$, clutch [-], gear number $[-]$ are obtained and the force exerted on the wheels $[\mathrm{N}]$ is determined.

- Section II "Drive system" - Enables projection of the real car's drive system operation, considering the diameter of the drive wheels [m], gear ratios and main transmission. This module transmits the signals necessary to control the engine simulation to further blocks torque $[\mathrm{Nm}]$ and crankshaft rotational speed $\left[\mathrm{rad} \cdot \mathrm{s}^{-1}\right]$.

- Section III "Engine" - The module performs the function of checking whether the previously obtained parameters of torque and rotational speed are within the acceptable ranges for this engine. In addition, the current value of power generated by the engine and average power for the entire test are determined in this part.

- Section IV "Calculations for petrol 95" - Standard petrol was used as the reference fuel in this model. Based on the hourly characteristics of fuel consumption as a function of the engine speed and torque, this block calculates the fuel and air consumption necessary to form the fuel-air mixture based on the following relationships (1), (2):

$$
f u e l=f u(\omega s, M s) / 3600, \mathrm{~g} \cdot \mathrm{s}^{-1}
$$

where $f u$ - function of hourly fuel consumption depending on the rotational speed and torque, $\left[\mathrm{g} \cdot \mathrm{h}^{-1}\right]$;

$\omega s$ - engine rotational speed, $\left[\mathrm{rad} \cdot \mathrm{s}^{-1}\right]$;

$M s$ - engine torque, $[\mathrm{N} \cdot \mathrm{m}])$.

$$
\text { air }=\text { fuel } \cdot \text { Ste }, \mathrm{g} \cdot \mathrm{s}^{-1}
$$

where fuel-fuel stream, $\left[\mathrm{g} \cdot \mathrm{s}^{-1}\right]$;

Ste - stoichiometric constant for petrol, $\mathrm{g}_{\text {aiu }} \cdot \mathrm{g}_{\text {fuel }}{ }^{-1}$.

Taking into account the calorific value of petrol, the energy flow resulting from fuel conversion and the temporary engine efficiency is then determined (3), (4):

$$
\begin{gathered}
E e=\text { Qe fuel, } \mathrm{J} \cdot \mathrm{s}^{-1} \\
\eta=M s \cdot \omega s / E e,
\end{gathered}
$$

where $Q e$ - calorific value of petrol, $\left[\mathrm{kJ} \cdot \mathrm{g}^{-1}\right]$.

- Section V "Calculations for fuels" - The section, divided into three blocks, enables the determination of the demand for a given fuel $\left[\mathrm{g} \cdot \mathrm{s}^{-1}\right]$ and the energy stream which is obtained from this fuel $\left[\mathrm{J} \cdot \mathrm{s}^{-1}\right]$.The following relationships havebeen used in this module (5), (6):

$$
\begin{aligned}
& \text { fuel }=\text { EelQe, } \mathrm{g} \cdot \mathrm{s}^{-1} \\
& \text { air }=\text { fuel } \cdot \text { Ste, } \mathrm{g} \cdot \mathrm{s}^{-1}
\end{aligned}
$$

where $E e-$ stream of energy from fuel, $\mathrm{J} \cdot \mathrm{s}^{-1}$.

Figure 1 is a schematic of the simulation model developed for the analysis. For the simulation model developed, the technical parameters used were those of the Fiat Seicen to city passenger car, equipped with a Fire $1.18 \mathrm{v}$ petrol engine generating $40 \mathrm{~kW}$. Table 1 below presents the basic technical parameters [25].

The next step was to choose the right vehicle cycle. Each passenger car is subject to an approval procedure before it is put into service, which specifies various parameters such as the vehicle's exhaust emissions or fuel consumption. These results then relate to the standards in force and, if they remain, such a vehicle shall obtain an approval certificate. For the vehicle selected for analysis, the applicable approval test is NEDC (New European Driving Cycle). The test consists of two parts: an urban cycle and an extra-urban cycle, which are intended to reflect the vehicle's actual traffic conditions. 


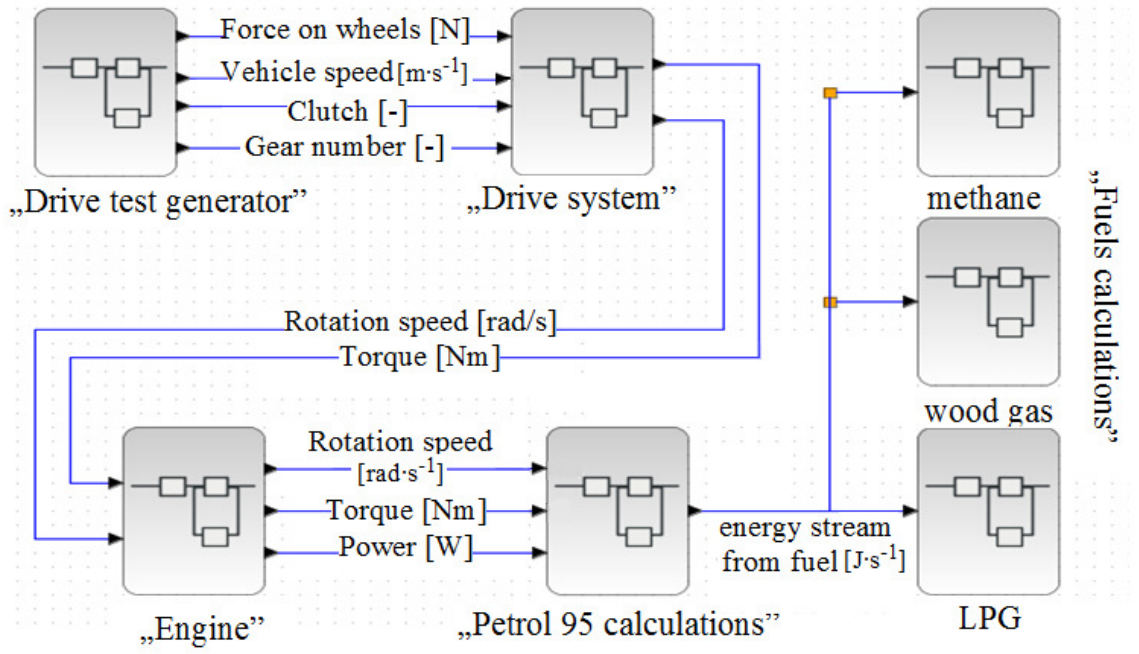

Fig. 1. Diagram of the simulation model

In the urban part therearefouridentical mini cycleswhere the car accelerates to $15 \mathrm{~km} \cdot \mathrm{h}^{-1}$, $32 \mathrm{~km} \cdot \mathrm{h}^{-1}$ and $50 \mathrm{~km} \cdot \mathrm{h}^{-1}$. Aftereachreferencespeedachieved, the vehiclestops. The out-of-town part is a reflection of motorwaydriving. Thereare no stopshere, just a slowdown to $50 \mathrm{~km} \cdot \mathrm{h}^{-1}$. The threespeeds the vehicleisaiming for are $70 \mathrm{~km} \cdot \mathrm{h}^{-1} 100 \mathrm{~km} \cdot \mathrm{h}^{-1}$ and $120 \mathrm{~km} \cdot \mathrm{h}^{-1}$. Throughout the entire test, the vehiclecovers a total of $11 \mathrm{~km}$ atanaveragespeed of $34 \mathrm{~km} \cdot \mathrm{h}^{-1}$ [26;27].

Specification of the 1.1 Fire 8v engine

Table 1

\begin{tabular}{|c|c|c|}
\hline Parameter & Unit & Value \\
\hline Engine code & - & $176 . \mathrm{b} 2.000$ \\
\hline Engine capacity & $\mathrm{cm}^{3}$ & 1108 \\
\hline Piston diameter & $\mathrm{mm}$ & 70 \\
\hline Piston stroke & $\mathrm{mm}$ & 72 \\
\hline Engine power & $\mathrm{kW}$ & 40 \\
\hline Engine torque & $\mathrm{N} \cdot \mathrm{m}$ & 86 \\
\hline Number of cylinders & - & 4 \\
\hline Cylinder arrangement & - & in-line \\
\hline Type of injection & - & direct, multistage \\
\hline Compression ratio & - & $9.6: 1$ \\
\hline
\end{tabular}

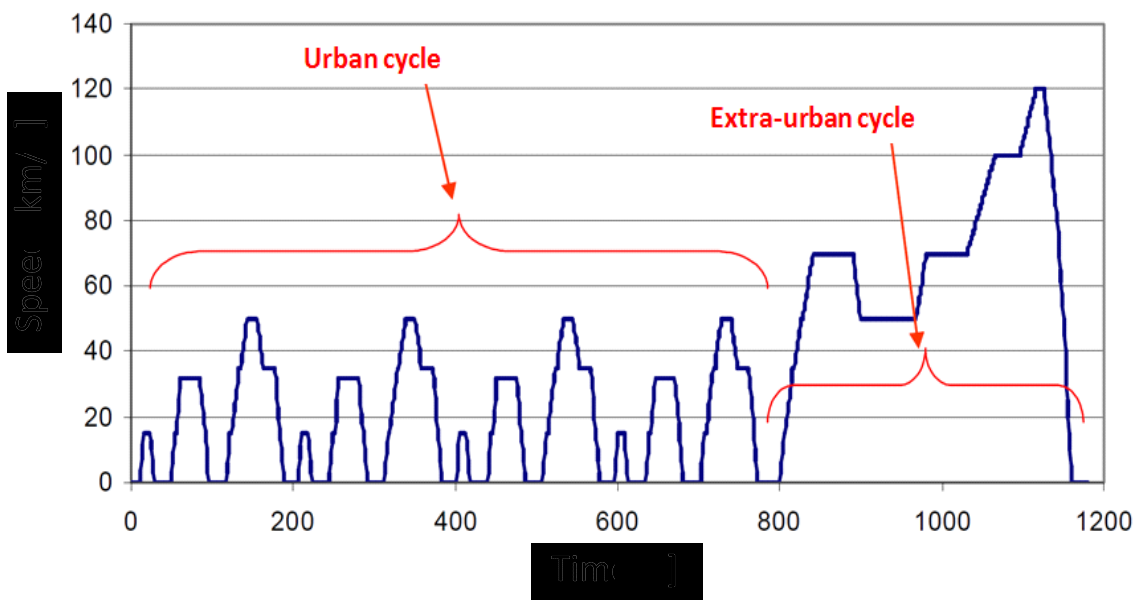

Fig. 2. Vehiclespeed in the NEDC test

In order to obtain correct results in the developed simulation it was necessary to use additional vehicle parameters such as: mass, rolling resistance, aerodynamic resistance. Table 2 lists the values of these parameters. 
Vehicle parameters relevant for the NEDC test

\begin{tabular}{|c|c|c|}
\hline Vehicle weight, $\mathbf{k g}]$ & Rolling resistance, $\mathbf{N}$ & Aerodynamic resistance, $\mathbf{N} /\left(\mathbf{k m} \cdot \mathbf{h}^{-\mathbf{1}}\right)^{\mathbf{2}}$ \\
\hline 740 & 5 & 0.0337 \\
\hline
\end{tabular}

Conventional petrol 95, LPG and alternative fuels such as biomass methane and wood gas were used as fuels in the simulation. The use of biomethane and wood gas based on waste fractions is a beneficial solution in the field of recycling waste material and, on the other hand, an increase in the share of renewable fuels. Table 3 below summarizes the properties of fuels used in the simulation that are relevant to the process of their combustion process in the engine. Conventional fuels that are currently used to power petrol units are also included. Table 3 below presents the parameters of fuels selected for testing that are significant from the point of view of the energy conversion process [28].

Table 3

Parameters of the analysed fuels

\begin{tabular}{|c|c|c|}
\hline Fuel & ${\text { Calorific value, } \mathbf{M J} \cdot \mathbf{g}^{-1}}$ & ${\text { Stoichiometric values, } \mathbf{g}_{\text {air }} / \mathbf{g}_{\text {fuel }}}$ \\
\hline LPG & 0.0461 & 15.7 \\
\hline Petrol & 0.043 & 14.7 \\
\hline Methane & 0.036 & 17.2 \\
\hline Wood gas & 0.0049 & 1.39 \\
\hline
\end{tabular}

Table 4 also shows the chemical composition of the wood gas used in the simulation.

Table 4

Chemical composition of wood gas

\begin{tabular}{|c|c|c|}
\hline Fuel & Symbol & Value, \% vol] \\
\hline Nitrogen & $\mathrm{N}_{2}$ & 47 \\
\hline Carbon monoxide & $\mathrm{CO}$ & 23 \\
\hline Hydrogen & $\mathrm{H}_{2}$ & 18 \\
\hline Carbon Dioxide & $\mathrm{CO}_{2}$ & 10 \\
\hline Methane & $\mathrm{CH}_{4}$ & 2 \\
\hline
\end{tabular}

\section{Results and discussion}

On the basis of the adopted assumptions and the developed model, a simulation was run of a petrol engine powered by individual alternative gaseous fuels and standard 95 petrol. In the first place it was important that the model should work correctly in accordance with the adopted schedule of the given road test. Figure 3 shows the charts of the engine operating parameters.
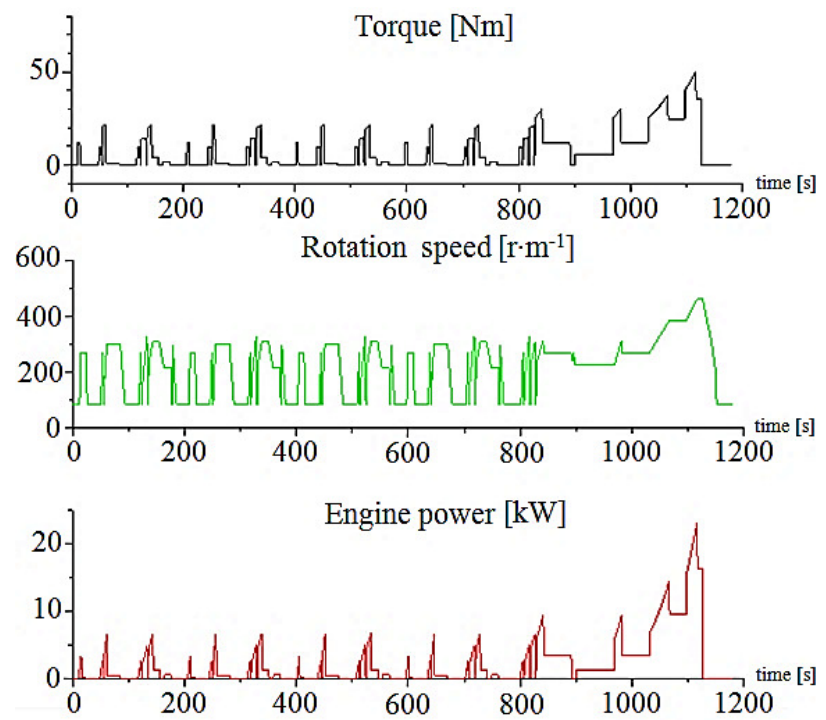

Fig. 3. Engine operating parameters 
The obtained charts coincide with literature data regarding the test used, so it was considered that the developed model works correctly and it is possible to carry out further simulations of the engine operation.

The next step was to determine the fuel consumption by the engine, air consumption and the fuelair mixture charge value which ensures optimal operating conditions for the drive unit for selected fuels. The values of the above parameters were obtained from the simulation and are summarized in Table 5 below:

Table 5

Air and fuel consumption in the test

\begin{tabular}{|c|c|c|}
\hline Fuel & $\begin{array}{c}\text { Mass fuel consumption, } \\
\mathbf{g} \cdot \mathbf{k m}^{-\mathbf{1}}\end{array}$ & $\begin{array}{c}\text { Mass air consumption, } \\
\mathbf{g} \cdot \mathbf{k m}^{-\mathbf{1}}\end{array}$ \\
\hline Petrol & 45.23 & 664.78 \\
\hline LPG & 41.20 & 646.85 \\
\hline Methane & 37.99 & 653.39 \\
\hline Wood gas & 387.62 & 539.47 \\
\hline
\end{tabular}

Based on the above results, it can be seen that petrol and LPG have the most similar values of fuel and air consumption. Interestingly, methane is also characterized by quite similar parameters. Wood gas, however, has a significantly higher mass consumption of fuel and lower demand for air in the stoichiometric mixture, which results from a relatively low calorific value for this fuel and a lower value of the stoichiometric constant.

In the last step, changes in the course of maximum power for individual fuels were determined. This criterion is extremely important from the point of view of operating a given power unit. It should be remembered that, the parameters of conventional fuels and the course of their combustion during conversion to energy are taken into account at the design stage of each engine. Engine power charts should therefore be close to the reference fuel due to the possibility of engine damage with too rapid growth. In turn, power drops affect the efficiency of the application.

Figure 4 shows the coursesof power values as a function of the engine rotational speed.

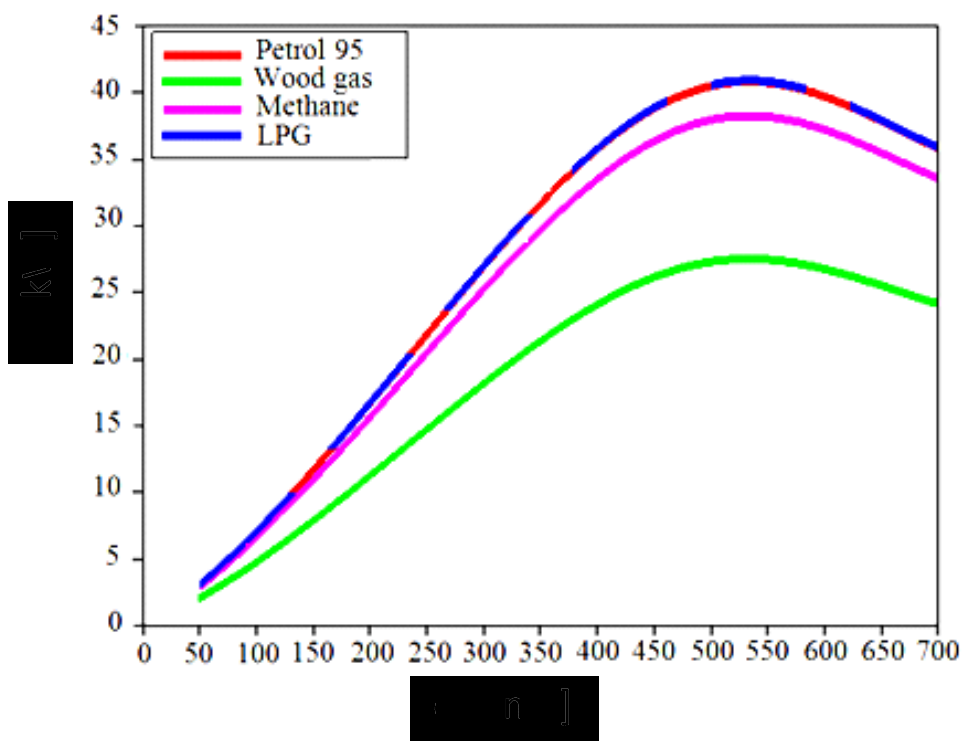

Fig. 4. Engine power chart

The course of the chart obtained clearly indicates that LPG is the fuel with the highest similarity to standard petrol. The two alternative fuels differ from conventional fuel values; particularly wood gas has a significant deviation. This is unfavourable from the point of view of the direct application of syngas as a standalone independent fuel, without prior modifications of the structure or fuel map of a given engine. Literature data on wood gas confirm its disadvantages in the form of low calorific value and lower power than in the case of reference fuels [18;29-31]. 


\section{Conclusions}

The analysis of the possibilities of using alternative gaseous fuels as transport fuels showed the following:

1. Each of the fuels used has different properties, both in terms of the performance parameters and the subsequent formation of the stoichiometric mixture, than petrol and LPG gas used. Methane has more than $16 \%$ lower calorific value than petrol and about $17 \%$ higher air demand when burning $1 \mathrm{~g}$ of fuel. Wood gas has almost $90 \%$ lower calorific value and more than $90 \%$ lower air demand for the conversion of $1 \mathrm{~g}$ of fuel, which translates into power drops in the fuel supply. The most similar parameters are those of conventional fuels.

2. In the case of methane, these differences are smaller, however, it also causes power drops during engine operation.

3. In the case of wood gas, the differences proved to be so great that its direct application could be associated with incorrect operation of the drive unit. Problems with fuel contamination and improper engine operation indicated in the literature could contribute to engine failure.

4. In the current situation, the fuel with greater potential to replace conventional energy carriers is methane. However, due to the possibility of reusing plentiful waste biomass, it is worth continuing the research into the use of wood gas for transport or into its treatment in order to bring its parameters closer to those of petrol.

\section{References}

[1] Mikielewicz D., Kosowski K., Tucki K., Piwowarski M., Stepien R., Orynycz O., Wlodarski R. Gas Turbine Cycle with External Combustion Chamber for Prosumer and Distributed Energy Systems. Energies, vol. 12, 2019,1-19.

[2] Gawlik L.,Mokrzycki E. Fossil fuels in the national power sector - problems and challenges. PolitykaEnergetyczna - Energy Policy Journal, vol. 20, 2017, pp. 6-26 (In Polish).

[3] Paszkiewicz, E. EU energy security constraints - selected issues. The scientific notebooks of the WSEI series: Administration: ZeszytyNaukowe WSEI seria: Administracja, vol. 7, 2017, pp. 133147.

[4] Rechul, H. Jaka jest różnica między ideą a zasadą zrównoważonego rozwoju?(What is the difference between an idea and the principle of sustainable development?). [online] [29.03.2020]. Available at: http://www.cire.pl/pliki/2/jakaroznic.pdf. (In Polish).

[5] Tucki K., Mruk R., Orynycz O., Wasiak A., Swic A. Thermodynamic Fundamentals for Fuel Production Management. Sustainability, vol. 11, 2019, pp. 1-19.

[6] Tucki K., Orynycz O., Swic A, Mitoraj-Wojtanek M. The Development of Electromobility in Poland and EU States as a Tool for Management of $\mathrm{CO}_{2}$ Emissions. Energies vol. 12, 2019, pp. 122.

[7] Lee H., Shao Y., Lee S., Roh, G. Chun K., Kang H. Analysis and assessment of partial reliquefaction system for liquefied hydrogen tankers using liquefied natural gas (LNG) and H2 hybrid propulsion. International Journal of Hydrogen Energy, vol. 44, 2019, pp. 15056-15071.

[8] Jeong J., Seo S., You H., Chang D. Comparative analysis of a hybrid propulsion using LNG-LH2 complying with regulations on emissions. International Journal of Hydrogen Energy, vol. 43, 2018, pp. 3809-3821.

[9] Burmistrz, P., Czepirski, L., Gazda-Grzywacz, M. Carbon dioxide emission in hydrogen production technology from coke oven gas with life cycle approach. [online] [28.04.2020]. Available at:

https://www.e3s-conferences.org/articles/e3sconf/pdf/2016/05/e3sconf_seed2016_00023.pdf

[10] How much carbon dioxide is produced from U.S. gasoline and diesel fuel consumption?. [online] [28.04.2020]. Available at:https://www.eia.gov/tools/faqs/faq.php?id $=307 \& t=11$

[11] Salvi B.L., Subramanian K.A.,Panwar N.L.Alternative fuels for transportation vehicles: a technical review. Renewable and Sustainable Energy Reviews, vol. 25, 2013, pp. 404-419.

[12] Tucki K., Orynycz O., Wasiak A., Swic A., Mruk R., Botwinska K. Estimation of Carbon Dioxide Emissions from a Diesel Engine Powered by Lignocellulose Derived Fuel for Better Management of Fuel Production. Energies 2020, vol. 13, pp. 1-29. 
[13] Olechowski A., Piaścik, M. Raport Roczny POGP 2018 (Annual Report POGP 2018).[online] [29.03.2020]. Available at: http://pogp.pl/wp-content/uploads/2019/04/POGP_2019RAPORT_420x297_internet.pdf. (In Polish).

[14] Sowa, A. Samochodowe instalacje zasilania gazem (Automotive gassupplysystems). First edition. Kraków: Dobry eBook, 2007. 96 p. (In Polish).

[15] Michałowski R., Więckowska J., Malewski S. Zastosowanie metanu jako paliwa do napędu silników (The use of methane as a fuel to the enginepropulsion). The Energy Market Journal: RynekEnergii, vol. 4, 2006, pp. 20-24. (In Polish).

[16] La Fontaine H., Zimmerman P. Drewno zamiast benzyny. Jak zbudować generator gazu drzewnego i jeździć samochodem ponad 5 razy taniej? (Wood instead of gasoline. How to build a wood gas generator and drive more than 5 times cheaper?) Second edition. Warsaw: Golden Thoughts: ZłoteMyśli, 2008; 91 p. (In Polish).

[17] Hetmańczyk I., Hepner W. Gaz generatorowy - biopaliwo z tradycjami (Generator gas - biofuel with tradition). Agricultural Engineering: InżynieriaRolnicza, vol. 4, 2012, pp. 91-100. (In Polish).

[18] Gil P., Wilk J. Instalacja CHP z silnikiem spalinowy mzasilany mgazemdrzewnym (CHP installation with a wood-fueled internal combustion engine) Technical Transactions. Mechanics: Czasopismo Techniczne. Mechanika, vol. 87,2015, pp.217-226 (In Polish)

[19] Kjellström B., Stassen H., Silva D. Wood Gas as Engine Fuel. Food and Agriculture Organization of the United Nations (FAO), Via-delle Terme di Caracalla, Italy, 1986.

[20] Hetmańczyk I., Hepner W. Gaz generatorowy - biopaliwo z tradycjami (Generator gas - biofuel with tradition).Agricultural Engineering: InżynieriaRolnicza, vol. 4, 2012, pp. 91-100. (In Polish).

[21] Brandin J., Tunér M., Odenbrand I., Lund, V. Small scale gasification: gas engine CHP for biofuels. Swedish Energy Agency Report, vol. 137, 2011.

[22] Piątkowski, P. , Bohdal, T. Testing of ecological properties of spark ignition engine fed with LPG mixture. RocznikOchronaŚrodowiska 2011, 13, 607-618.

[23] Kawa A., Fuks K., Januszewski, P. Computer Simulation as a Research Method in Management Sciences. Studia o economica posnaniensia, vol. 4, 2016, pp. 109-127.

[24] Prauzner T. Nowocz esnetechni kisymulacyjnezagrożeń w inżynieriib ezpieczeństwa (Modern techniques of simulation risks in safety engineering). Scientific Issues Jan Długosz University in Częstochowa. Technology, Computer Science, Safety Engineering: Prace Naukowe Akademii im. Jana Długosza w Częstochowie. Technika, Informatyka, InżynieriaBezpieczeństwa, vol. 2, 2014, pp. 253-265. (In Polish).

[25]Zembowicz, J. Fiat Seicento. First edition. Warsaw: Transport and Communication Publishers: WydawnictwoKomunikacjiiŁączności, 2010; 220 p.

[26] Barlow, T.J.; Latham, S.; McCrae, S.I.; Boulter. P.G. A reference book of driving cycles for use in the measurement of road vehicle emissions. [online] [29.03.2020].Available at: https://assets.publishing.service.gov.uk/

[27] Regulation No 83 of the Economic Commission for Europe of the United Nations (UN/ECE) Uniform provisions concerning the approval of vehicles with regard to the emission of pollutants according to engine fuel requirements. Available at: https://eur-lex.europa.eu/

Flekiewicz M., Kubica G. Badania przebiegu procesuspalania alternatywny chpaliwgazowychi ich mieszanek $\mathrm{z}$ wodorem $\mathrm{w}$ silniku ZI (Examination of combustion process of alternative gaseous fuels and their mixtures enriched by hydrogen in a SI engine). Technical Transactions. Mechanics: CzasopismoTechniczne. Mechanika, vol. 105, 208, pp. 151-160.

[28] Kjellström B., Stassen H., Silva D. Wood Gas as Engine Fuel. Food and Agriculture Organization of the United Nations (FAO), Via-delle Terme di Caracalla, Italy, 1986.

[29] Papagiannakis R. G., Zannis T. C. Effect of wood-gas composition on performance and exhaust emission characteristics of a large spark-ignition engine. Journal of Energy Engineering, 140(3), 2014.

[30] Papagiannakis R. G., Zannis T. C. Thermodynamic analysis of combustion and pollutants formation in a wood-gas spark-ignited heavy-duty engine. International journal of hydrogen energy, 38(28),2013, pp.12446-12464.

[31] Piętak A., Duda, K., Chraplewska, N. (2010). Possibilities of supplying internal combustion engines by wood gas. Journal of KONES vol. 17, 2010, pp. 369-376. 